\title{
The Study of Interactive Relationship between Teaching and Learning in College English Teaching
}

\author{
Xue $\mathrm{Ni}$ \\ School of Foreign Studies Xi'an University 710065
}

Keywords: College English, teacher-student interaction, construction

\begin{abstract}
With the economic and social development, the demand for talents in our country grows exponentially. In the context of quality education, we should pay more attention to the quality of talent cultivation while paying attention to the number of talent cultivation. Under the new situation, the traditional teaching mode has become the fetter of teaching development. In the college English classroom, the interactive relationship between teaching and learning can exert the enthusiasm, initiative and creativity of students, which has become one of the important factors to promote the quality of English teaching. Therefore, college English teachers should adopt positive teaching methods and strategies to permeate the concept of teacher-student interactive relationship between teaching and learning to the teaching of college English, and actively promote the interaction of teachers and students in college English classroom. This article starts from the necessity of the interaction relationship between teaching and learning in college English teaching and puts forward some strategies to construct the interactive relationship between teaching and learning in college English teaching from several aspects, so as to improve college English teaching quality.
\end{abstract}

\section{Situation Analysis of Interaction between Teaching and Learning in College English Teaching}

\section{The Knowledge Levels of the Teachers need to be Improved}

As the main body of English teaching, the knowledge level of teachers is directly related to the level of teaching quality. In English teaching in China, English teachers with high professional quality are still very scarce. The vast majority of English teachers' knowledge system is incomplete. With the progress of the times, the teaching of English should also advance with the times. What teachers need to do is guide students so that those students who are interested in English can improve their understanding of English knowledge and lay a good foundation for them to enter society. It also requires teachers to prepare the most representative cases to carry out teaching activities during lesson preparation. Teachers can also organize after-school study groups to consider some contents students are interested in as topics of discussion and organize study groups to conduct in-depth research and discussions to enhance students' interest. However, nowadays the levels English teachers in colleges and universities in our country still fail to achieve such a level, and the teacher's knowledge system needs to be further improved.

\section{The Multimedia Teaching Resources Are Scarce}

Computer-aided instruction originated in the United States in the 1960s, and later developed in our country. Until now, the way of computer-aided instruction is still not universal in major colleges and universities. Although China's economy develops rapidly, its investment in education is relatively small, which is specifically reflected in the extent of the use of multimedia facilities. However, there is a great difference between the use of multimedia facilities in English teaching and other disciplines. English requires not only classroom teaching but also multimedia teaching to achieve the goal of teaching. However, due to the backwardness of multimedia facilities in colleges and universities in our country, multimedia teaching has not been popularized in many teaching links. If teachers can use multimedia for teaching, the motivation and enthusiasm of student learning will be stimulated. At the same time, multimedia teaching can bring the most advanced cultural information to the classroom. Learning a foreign language does not mean to just learn the grammar and sentence patterns. The multimedia teaching can make up for such defects, which can integrate the sound, images, pictures together, making the teaching content more three-dimensional and more visual. 


\section{Attaching importance to Teaching rather than Learning}

Teachers should definitude the teaching objectives. In terms of the design of the teaching process, teachers should not only focus on teaching content, but do not pay attention to the actual requirements of students. Teachers should focus on teaching how to complete the teaching process, and put it into practice. The traditional teaching of classroom teaching is based on the teacher, emphasizing the teaching of knowledge and neglecting the learning motivation of the students. This makes students lose interest and motivation in the process of learning, thus making the teaching quality lower. When the teaching is carried out, the teacher regards himself as a storytelling person who is satisfied with a single way and a single point of view. In this way, the teaching requirements cannot be achieved.

\section{Teaching is too Traditional}

Too old-fashioned teaching is difficult to break away from the "teacher-centered" teaching system. In this classroom teaching system, students are in a passive state of learning without opportunities to speak, and the classroom atmosphere is not active. Teachers ask questions in the classroom, and students often do not get the idea of expansion, and the response is slow, thus the student's answers are not satisfactory. College English teaching emphasizes the interaction between teachers and students. There is no point in the English class without communication process. Full communications are the key factors in the success of the English class. Teachers in the classroom should choose the appropriate form, so that students actively participate in the classroom, reflecting its subjective initiative. Effective interaction between teachers and students is conducive to the construction of learners as the main body, guiding students to think independently based teaching system. The English teaching activities change from the "teaching-oriented" model to a "learning-based" model, and the relationship between teachers and students also changes from the traditional cramming method of teaching to interactive teaching.

\section{Necessity of Constructing Interactive Relationship between Teaching and Learning in College English Teaching}

Before creating the interactive relationship between teachers and students in college English teaching, we should correctly understand the meaning of interaction between teachers and students. As a unique form of interpersonal interaction, teacher-student interaction is actually the interactions and mutual influences between teachers and students. The process of interaction between teachers and students is an embodiment of the learning process. Throughout the learning process, students are the main body of learning, and the teacher plays the role of guiding students to learn. Without the active participation and interaction of students, classroom teaching will lose its value it should have, and become the cramming method of teaching. The communication and exchange between teachers and students are not limited to the classroom but can also be carried out after school hours and in life. Its importance is mainly reflected in the following points:

The Current Situation of College English Teaching Determines the Necessity of the Interaction between Teaching And Learning

Nowadays, most college English teaching in our country adopts the form of multi-majors teaching in large classes. However, college English is not a specialized course for students, so students are not paying enough attention to English and do not have enough enthusiasm to learn it. In addition, the vast majority of institutions of higher learning do not carry out the English teaching system by different level. The students' English level is different, making a lot of students do not understand the process of learning, and gradually lose the desire and interest of learning.

The Requirements of Interactive Relationship between Teaching and Learning in College English Teaching in New Age

As globalization continues to advance, our country is increasing in the demand of English talents. The demand for talents has also changed from the traditional written translation to a qualified one with the full range of skills of "listening, speaking, reading, writing and translating." The traditional dumb English has been far unable to meet the needs of society and the times. Therefore, in the process of conducting English teaching in universities and colleges, the establishment of 
teacher-student relationship has become crucial. The traditional teaching system will be forgotten by the times and replaced by a teaching system that is adapted to the development of the times.

Interaction between Teachers and Students Can Stimulate Students' Enthusiasm for Learning and Mobilize the Enthusiasm of Learning English

In the past English teaching mode, teachers tend to prefer good students, which makes the introverted or underperforming students get less attention from the teachers. In the long run, this will lead to serious polarization. In order to prevent this phenomenon, we must form a good interactive relationship between teachers and students, which requires teachers to form a good interaction with all students. Teachers should encourage and concern the students with poor learning foundation or introversion, motivating them to express their thoughts and opinions in English in class. Teachers should also continue to encourage and affirm these students so that they can gain motivation.

\section{Strategies and Methods of Constructing Interactive Relationships Between Teaching And Learning In College English Teaching}

In-depth study of the process of college English teaching activities, in view of the lack of interactive relationship between teachers and students, some measures and methods have been put forward to optimize the interaction between teachers and students. In this way, college English teaching can be optimized and teaching quality and efficiency can be improved greatly, so that colleges can cultivate excellent college students with better comprehensive quality. In order to create a good interactive relationship between teachers and students, we should make continuous efforts based on the following points:

\section{Establishing a Good and Harmonious Interaction between Teachers and Students}

As we all know, in the past teaching mode, the teacher is the classroom manager and controller, and usually does not let the students send out their own signals. This leads to the absolute authority of the teacher, and students must obey the teacher, which conflicts with the idea that the student is the subject of study, not to mention the interaction and communication between teachers and students. So, in order to form a good interaction between teachers and students in the process of college English teaching activities, teachers should strive to create a democratic, equal and harmonious atmosphere during the teaching activities. This is because the formation of good interaction between teachers and students is based on equality between teachers and students. If the relationship between teacher and student is not equal, then it is impossible to build a good interaction. Therefore, to form a good interaction between teachers and students, teachers need to uphold respect to treat all students, and teachers become the creator of the good interactive relationship between teachers and students. In the good interactive relationship between teachers and students, a good cycle of interactive learning can be truly formed, which in turn enables students to fully mobilize the enthusiasm and initiative of learning, and teachers become real mentors for students.

\section{Enhancing the Emotional Interaction between Teachers and Students}

While carrying out English teaching activities, most universities and colleges only focus on "teaching" and "learning" in the classroom, but do not pay attention to the interaction and exchange between teachers and students. In the process of teaching activities, teachers merely correct the students' attitudes towards learning English or simply familiarize themselves with each other, which in turn make the classroom atmosphere relax and lively. This is just the basic needs of the emotional exchange. In fact, when English teachers start their studies in the new semester, they do not need to urgently introduce new knowledge to their students. Teachers can introduce themselves briefly, and students also introduce their own basic situations. They can learn about each other's personalities and hobbies. This will enable teachers and students to build a preliminary emotional cooperation, thus making the emotional exchange easier in the future. In addition, when teaching daily knowledge, teachers should interact and communicate with students in a timely manner. During the class, teachers can ask students about their lectures or their after-school learning. This will not only improve students' escalation, but also enhance emotional interaction between teachers and students. 


\section{Using Modern Teaching Methods for Classroom Interaction between Teachers And Students}

Nowadays, due to the rapid economic development in China, the teaching infrastructure in domestic universities has been greatly optimized. Most colleges and universities are now beginning to use multimedia teaching methods to carry out teaching activities. In terms of English teaching, they can also provide Internet multimedia audio classrooms. Therefore, college English teachers must make good use of the existing multimedia teaching facilities and equipments, with the aid of such resources as images, three-dimensional movies or video conversations, so as to enhance the audio-visual effects and further stimulate the enthusiasm and initiative of students in learning, which in turn makes the interaction between teachers and students stronger and ultimately leads to the improvement of teaching quality and efficiency.

\section{Organizing Students to Interact in Groups}

Teachers play a leading role in the process of teaching activities. However, because of the large number of students, teachers should not only communicate and exchange with students in class, but also guide students to carry out activities in groups so as to form a good communication relationship among students, and thus optimize the interaction between teachers and students from the side. In class, the teacher can subdivide the students into groups of 3 to 5, provide some topics and start group discussions. Afterwards, each group sends one or two representatives to explain the group's views and opinions in the class. Definitely, after class, a group of students can be formed as well, and representatives from the group can communicate and exchange with the teachers so as to make the interaction and exchange between teachers and students more frequent. In addition, in accordance with the teaching methods abroad, students are allowed to form a group of themselves to conduct oral English training. After practice, several groups of students can be selected to display the results of their training in class. In this way, with the interaction and exchange among students, the interaction between teachers and students can be improved and the efficiency and quality of teaching can be greatly improved.

\section{Enhancing Teacher-student Interaction Outside of Class}

College English has fewer class hours, which leads to some limitations of the interaction between teachers and students. Therefore, universities and colleges should create opportunities for teachers and students as much as possible so that they can interact and communicate with each other in an in-depth manner. For example, teachers use the modern Internet platform to communicate with and interact with students after class. In addition, college English teachers can recommend high-quality English language learning websites, English articles, and so on to students through Internet public platforms such as public emails and campus English forums. This approach does not have a spatial and temporal impact so that students can make full use of their spare time, with the resources provided by the Internet teaching platform or the English learning platform recommended by the teachers to continuously improve their English level.

\section{Grasping the Interaction between "Teaching" and "Learning"}

In English teaching activities, teachers and students are the main body. The teachers should not only have their own sense of innovation, but also guide students to form a sense of innovation. The guiding role of the teacher and the main role of the students are all reflected in the teacher's teaching which is to serve the students. Therefore, teaching and learning is a strong interactive activity.

When carrying out teaching activities, teachers should pay attention to the cultivation of students' thinking ability, especially the cultivation and enhancement of creative thinking. The main content of innovation ability is actually creative thinking. It is also a complicated and advanced thinking process. It is also the source of all creative activities and the core of innovative education. During the process of teaching activities, teachers should have more levels of training in planning, targeting students' imagination, divergent thinking, radiation thinking, associative thinking, analogical thinking, and reverse thinking. For example, the divergent thinking of the students is strengthened by means of the form of "polysemy" and "a sentence with more than one translation" in the course of lexical and syntactic teaching. "Pre-reading prediction" and "generalization and summarization" 
in the process of reading training, and "association of pronunciation and meaning" in the phonetic teaching activity are used to strengthen divergent thinking, associative thinking, analogical thinking and creative thinking of the students. In the course of carrying out teaching activities, teachers use "problem-based" teaching methods to attract students from all aspects to encourage students to express their ideas and suggestions on the basis of the problems so as to greatly enhance students' analogical thinking, associative thinking, and divergent thinking.

\section{Conclusion}

At present, the interactive relationship between teachers and students in college English classroom teaching is not yet perfect. Based on the above analysis of the problems existing in the interaction between teachers and students, some countermeasures are put forward. The following suggestions can be provided to college English teachers in class teaching: to abandon the false interaction; to strive to build a real and effective interaction between teachers and students in order to improve English classroom teaching efficiency and promote the harmonious development of the overall quality of students.

\section{Reference}

[1] Li X.M.: How to promote the interaction between teachers and students in college English class [J]. Modern Enterprise Education, 2016(08): 40-50. In Chinese.

[2] Xie X.Q.: Strategies for interaction between teachers and students in college English class [J]. Education for Chinese After-school(Theory), 2016(08): 40-50. In Chinese.

[3] Xue G.P.: Teacher-student interaction and college English classroom teaching [J]. Journal of Weinan Teachers College, 2016(08): 40-45. In Chinese.

[4] Huang B.: The construction of harmonious relationship between teachers and students in college English teaching [J]. Journal of Suzhou Education Institute, 2015(02): 23-24. In Chinese.

[5] Wang Y.: Emotional factors in college English teaching [J]. The South of China Today, 2015(12): 40-41. In Chinese.

[6] Ma Z.: On the teacher-student interaction of feelings in classroom teaching of college English [J]. Journal of Xi' an Eurasia University, 2015(4): 22-23. In Chinese.

[7] Lai Q.Z.: Interactive mode in college English teaching [J]. China Adult Education, 2015(11): 23-24. In Chinese.

[8] Ma Z.Y.: A study of Chinese cognitive structure in the interaction of college English classroom teachers and students [J]. Science \& Technology Information, 2010(28): 40-41. In Chinese.

[9] Yan Y.Z.: Strategies for strengthening interaction between teachers and students in college English class [J]. Kaoshi Zhoukan, 2015(28): 44-45. In Chinese.

[10]Liu M.: The interactive distortion between teachers and students in college English class teaching and countermeasures [J]. Theory Research, 2010 (18). In Chinese.

[11]Peng X.M.: Research on interactive mode between teachers and students in college English classroom [J]. China Education Innovation Heral, 2016(34):20-23. In Chinese.

[12]Luo H.X.: An analysis of the factors influencing the interaction between teachers and students in college English class teaching [J]. Journal of Hubei University of Economics (Humanities and Social Sciences), 2015(10):40-41. In Chinese. 